\title{
KOMPONEN PENGKAJIAN DALAM PROSES KEPERAWATAN
}

\author{
ANGEL OKTAVIA PURBA / 181101099 \\ angeloktavia013@gmail.com
}

\begin{abstract}
ABSTRAK
Pengkajian adalah langkap awal dalam proses keperawatan dimana pada tahap pengkajian dilakukan secara sistematis. Pengkajian merupakan komponen kunci dan pondasi proses keperawatan. Pengkajian membuat data dasar dan merupakan proses dinamis. Pada pengkajian kegiatan yang dilakukan adalah mengumpulkan data sepeti riwayat keperawatan, pemeriksaan fisik, dan pemeriksaan data sekunder lainnya. Dalam tahap ini diperlukan pengkajian yang cermat untuk mengenal masalah klien agar dapat memberi arah kepada tindakan yang akan diberikan.Tujuan penulisan ini adalah untuk mengetahui apa saja tahapan dalam kegiatan pengkajian, tujuan dilakukannya pengkajian, serta bagaimana pelaksaaan dalam tahap pengkajian tersebut. Adapun Metode penulisan ini adalah Literature Riview, dimana ini menganalisis artikel yang relevan dan berfokus pada tema yaitu komponen pengkjian dalam proses keperawatan Mengingat pengkajian merupakan tahap awal maka diperlukan maka setiap perawat agar diharapkan agar lebih melatih keterampilan melakukan pengkajian serta dalam proses keperawatan perawat dituntut untuk lebih berpikir krtitis dalam setiap tahaap dalam proses keperawatan.
\end{abstract}

Kata Kunci: Proses keperawatan, Pengkajian dalam keperawatan,Dan tahapan pengkjian dalam proses keperawatan.

\section{LATAR BELAKANG}

Seiring dengan perkembangan zaman, tentunya di dalam dunia keperawatan juga semakin berkembang baik dari keilmuan dan praktik keperawatan juga turut berkembang. Berbagai penelitian dari berbagai bidang juga berkembang berdasarkan fenomena yang terjadi dalam dunia pelayanan keperawatan dilakukan.Perawat sebagai suatu profesi yang merupakan bagian dari tim kesehatan dimana tugas dari seorang perawat adalah memberikan pelayanan kesehatan kepada setiap individu, keluarga dan masyarakat. Dalam dunia keperawatan, asuhan keperawatan merupakan tulang punggung pelayanan dalam pelayanan kesehatan di Rumah sakit. Pemberian asuhan keperawatan ditujukan untuk pemenuhan kebutuhan dasar klien guna tercapainya dan dapat dipertahankannya kondisi sehat yang optimal. Untuk mencapai tujuan tersebut tentunya dibutuhkan pendekatan dengan metode ilmiah yang 
sistematis sehingga pelayanan yang diberikan optimal. Keperawatan dalam arti yang sangat luas merupakan perbuatan yang membantu klien dengan memberikan pelayanan kesehtan . Dan bantuan yang diberikan tidak dapat dilakukan bila perawat tidak memahami pola individualisasi untuk semua aktivitas pelayanan. Untuk mencapai semua hal tersebut maka harus dibutuhkan suatu pendekatan dengan mode ilmiah yang sistematis sehingga dapat memecahkan masalah klien metode tersebut dinamakan metode keperawatan yaitu suatu metode yang sistematis dan terorganisasi dalam pemberian asuhan keperawatan.Dalam proses keperawatan terdapat beberapa tahapan proses keperawatan yaitu pengkajian, diagnose, perencanaan, implementasi dan evaluasi. Setiap tahap proses keperawatan saling terkait dan ketergantungan satu sama lain. Untuk itu dalam memberikan asuhan keperawatan tentunya seorang perawat harus melaksanakan tahap-tahap dalam proses keperawatan tersebut secara benar dan tepat agar tidak terjadi kesalahan sehingga asuhan keperawatan yang diberikan dapat berjalan secara optimal.

\section{TUJUAN}

Tujuan dari penulisan ini yaitu agar dapat menegetahui apa itu proses keperawatan, mengetahui apa itu tahap pengkajian dalam proses keperawatan, apa tujuan dilakukannya pengkajian dalam proses keperawatan dan bagaimana pelaksanaan tahap pengkajian dalam proses keperawatan tersebut.

\section{METODE}

Metode penulisan ini adalah Literature Riview, dimana ini menganalisis artikel yang relevan dan berfokus pada tema yaitu komponen pengkjian dalam proses keperawatan. Adapun sumber yang digunakan dalam literature ini menggunakan sumber dari buku teks, jurnal dengan memasukan kata kunci komponen pengkajian dalam proses keperawatan, tahap pengkajian dalam proses keperawatan. Adapun jurnal yang saya yang digunakan merupakan jurnal yang diiterbitkan pada 10 tahun terakhir. 
HASIL

Berdasarkan pencarian literature didapatkan apa pengertian proses keperawatan, mngetahui apa defenisi pengkajian dalam proses keperawatan, selain itu berdasarkan pencarian literatute ini didapatkan juga apa tujuan dilakukannya pengkajian dalam proses keperawatan dan bagaimana pelaksanaan tahap pengkajian tersebut dalam proses keperawatan.

\section{PEMBAHASAN}

Proses keperawatan adalah suatu pendekatan dalam pemecahan masalah, sehingga perawat dapat merencanakan dan memberikan assuhan keperawatan (Potter \& Perry, 1997). Kemudian menurut Yura Walsh (1983) proses keperawatan adalah suatu tahapan desai tindakan untuk memenuhi tujuan keperawatan. Tahapannya meliputi desain tindakan dalam mempertahankan kesehatan klien pada keadaan optimal. Adapun tujuan proses keperawatan secara umum yaitu adalah membuat kerangka konsep berdasarkan kebutuhan individu atau klien, keluarga dan masyarakat (Carpenito dan Moyet 2007). Pelaksanaan proses keperawatan akan membuat seorang perawat dapat menyelesaiikan suatu masalah dengann pendekatan yang ilmiah, sistematis dan logis sehingga menghasilkan pelayanan yang berkualitas kepada individu, keluarga dan masyarakat. Proses keperawatan sendiri terdiri atas lima tahapan yaitu : pengkajian, diagnosis, perencanaan, implementasi dan evaluasi, yang dimana kelima tahap dari proses keperawatan ini saling terkait dan ketergantunga satu sama lain. Pada tahap pengkajian dimana tahap pengkajian merupakan tahap awal dalam landasan proses keperawatan. Pada pengkajian kegiatan yang dilakukan adalah mengumpulkan data sepeti riwayat keperawatan, pemeriksaan fisik, dan pemeriksaan data sekunder lainnya. Dalam tahap ini diperlukan pengkajian yang cermat untuk mengenal masalah klien agar dapat memberi arah kepada tindakan yang akan diberikan. Keberhasilan proses keperawatan sangat tergantung pada ketelitiam, kecermatan dalam proses keperawatan. Pada dasarnya tujuan dari pengkajain yaitu untuk mengumpulkan dat objektif dan subjektif dari klien.Dan Menetapkan dasar tentang kebutuhan, maslakah kesehatan ,tujuan, nilai dan gaya hidup yang dilakukan klien Adapun data yang terkumpul mencakup informasi klien, 
keluarga, masyarakat, lingkungan atau budaya ( Mc Farland, 1997). Adapun Hal yang harus diperhatikan selama pengkajian yaitu : Memahami bahwa klien adalah sumber informasi primer, sumber anggota sekunder meliputi anggota keluarga, orang yang berperan penting dan catatan kesehatan klien. Ketigaa yaitu memahami secara keseluruhan situasi yang sedang dihadapi oleh klien dengan cara memperhatikan kondisi fisik, psokologi, emosi, dan spitual yang dapat mempengaruhi kesehatan klien.

Keempat yaitu mengumpulkan semuaa informasi yang bersangkutan dengan masa lalu dan saat ini bahkan sesuaitu yang berpotensi mempengaruhi kesehatan pasien. Pada tahap pengkajian terdapat 4 kegiatan yaitu (1) Pengumpulan data (2) pemeriksaan data data (3) penilaian data dan (4) pengorganisasian atau pengelompokan data. Pada tahap pengumpulan data yang merupakan kegiatan dalam menghimpun informasi data-data dari pasien, yang meluputi unsur biopsikososio spiritual yang komprehensip. Pengumpulan data juga merupakan suatu proses pengkajian dengan pengumpulan informasi tentang status kesehatan klien secra sistematis dan terus menerus. Pengkajian dimulai sejak klien masuk ke Rumah sakit dan diteruskan sampai klien pulang. Adapun sumber data yang bisa digunakan dalam mengumpulkan data yaitu : klien, keluarga, masyarakat, orang-orang terdekat klien, catatan keperawatan, rekam medic, konsultasi secara verbal atau tulisan, pemeriksaan diagnostic dan literature yang berkakitan. Agar dapat terkumpulnya data dengan baik dan terarah sebaiknya dilakukan peggolongan atau klasifikasi data. Metode pengumpulan data tang digunakan yaitu dengan cara wawancara dimana diperlukan untukk data yang mungkin didapat melalui observasi dan pemeriksaan untuk data yang tidak mungkin didapat melalui obsevasi dan pemeriksaan fisik. Data tentang riwayat kesehatan klien dan keluhan klien di dapaat melalui wawancara. Selain itu, melalui wawancara perawat juga mendapatkan kesempatan untuk membina hubungan interpersonal. Dalam membina hubungan salling percaya dengan klien, penting sekali bagi perawat untuk memperkenalka diri dan menjelaskan tujuan dilakukannya wawancara. Adapun jenis data yaitu data subjektif dan data objektif. Data subjektif adalah data yang didapatkan 
melalui wawancara. Data yang bisa didapat melaluui wawancara ini meliputi identitas diri klien, riwayat kesehatan dan perawatan, riwayat perawatan dan kesehatan, kondisi kesehatan yang memerlukan pengobatan, respon kiln terhadap penyakit, faktor sisoal, dukungan social, dan budya, praktik dan kepercayaan tentang kesehatan, aktivitas sehari-hari, bagaimana klien megatasi kaluhan termasuk efek samping dari pengobatan dan bagaimana persepsi klien terhadap penyankitnya. Contoh data subjektif : "klien mengatakan saya merasakan sakit perut" contoh kedua yaitu" , Pagi hari tadi klien mengatakan " saya merasakan nyeri pada tubuh sebelah kanan “ Kemudian data objektif yaitu data yang diperoleh melalui hasil observasi atau pemeriksaan. Data ini yaitu data yang dapat dilihat, dirasa, didengar atau dicium. Disebut juga dengan tana atau gejala. Data didapatkan melalui pemeriksaan fisik dan observasi perilaku klien. Contoh data objektif yaitu : tekanan datah 120/70, kemerahan pada tanngan, klien sesak ketika bernafas dan terdapat edema pada bagian kaki. Data seperi contoh diatas didapat ketika dilakukannya observasi dan pemeriksaan fisik yang dilakukan perawata.

Kemudian tahap pengkajian kedua yaitu tahap Klafikasi data dimana data subjektif dan data objektif yang telah ditemukan kemudian diidentifikasi sebagai gejala. Gejala disini dimaksud yaitu data yang tepat untuk membuat keputusan, apakah itu merupakan suatu masalah atau bukan. Contoh dari pemeriksaan data yaitu data subjektif : “ saya merasakan gatal pada bagian dada saya" data objektif : “Perawat menemukan kemerahan pada seluruh bagian tubuh atas pasieen". Data diatas memberikan gejala yang menunjang kea rah masalah yang dicurigai yaitu kemungkinan klien mengalami alergi . Bagaiamana perawat meninterpretaasikan data diatas adalah proses penyimpulan atau pemeriksaan data. Kemampuan mengidentifikasi tanda dan gejela serta membuat keputusaan yang tepat akan memengaruhi keterampilan, pengetahuan,dan keterampilan praktik dalam mengobservasi.Tahap ke tiga dalam pengkajian yaitu Penilaian data atau analisa data dan perivikasi terhadap informasi yang di dapatkan secara nyata dan komplit adalah bagian dari proses berpikir kritis. Hal ini akan membantu 
anda untuk menghindari seperi membuat asumsi, kehilangan data yang penting, salah mengerti situasi, salah dalam kesimpulan dan arah dan agar membantu agar tidak membuat kesalahan dalam identifikasi. Contohnya ketika perawat bertanya kepada klien apakah ia sedang Hamil atau tidak, bila jawaban klien adalah "tidak" maka jangan lakukan verivikasi misalnya dengan mengajukan pertanyaan " kapan menstruasi terakhir anda?". Hal ini membahayakan karena klien akan merasa terancam. Tahap pengkajian yang selanjutnya yaitu Pengorganisasian atau Pengelompokan data dimana merupakan suatu bagaian dalam proses berpikir kritis untuk meningkatkan kemampuan dalam menginterpretasi status kesehayan klien. Banyak cara untuk mengelompokkan data, masing-masing perawat dapaat memilih cara terbik. Salah satu cara adalah teori Abraham Maslow yang berpendapat bahwa semua manusia mempunyai kebutuhan dasar umum yang terdiri dari beberapa tingkatan, dimana tingkatan kebutuhan dasar harus terpenuhhi lebih dahuulu sebelum kebutuhan tingkat yang lebih tinggi. Jadi pengelompokan data tersebut berdasarkan tingkatan yang terlebih dahulu dan terpenting kemudian dilanjutkan ke bagian kebutuhan lainnya. Kemudian tahap terakhir dalan tahap pengkajian yaitu tahap Pendokumentasian hasil pengkajian, tahap akhir dari pengkajian adalah pendokumentasian data yamh meliputi pencatatan dan pelaporan. Hal-hal yang harus diingt dalam mencatat adalah akurat dan berpikir kritis, dimana catatan akan akurat dan lengkap bila ditulis saat masih segar dalam ingatan. Menulis informasi dan melakukan evalusi akan membantu untuk menginterpretasikan makna dan datadata yng hilang, dan akan meningkatkan kemampuan berpikir kritis. Prinsip yang harus diterapkan dalam membuat dokumentasi hasil pengkajian adalah memutuskan apa yang akan dilaporkan.

\section{PENUTUP}

\section{KESIMPULAN}

Proses keperawatan adalah suatu pendekatan dalam pemecahan masalah, sehingga perawat dapat merencanakan dan memberikan assuhan keperawatan (Potter \& Perry, 1997). Proses keperawatan sendiri terdiri atas lima tahapan yaitu : pengkajian, diagnosis, perencanaan, implementasi dan evaluasi, yang dimana kelima tahap dari 
proses keperawatan ini saling terkait dan ketergantunga satu sama lain. Pada tahap pengkajian dimana tahap pengkajian merupakan tahap awal dan landasan proses keperawatan. Pada tahap pengkajian terdapat 5 kegiatan yaitu (1) Pengumpulan data (2) pemeriksaan data data (3) penilaian data dan (4) pengorganisasian atau pengelompokan data pendokumentasian hasl pengkajian. Pada tahap pengumpulan data yang merupakan kegiatan dalam menghimpun informasi data-data dari pasien, yang meluputi unsur biopsikososio spiritual yang komprehensip. Kemudian tahap pengkajian kedua yaitu tahap pemeriksaan data dimana data subjektif dan data objektif yang telah ditemukan kemudian diidentifikasi sebagai gejala. Tahap ke tiga dalam pengkajian yaitu Penilaian data dan verivikasi terhadap informasi yang di dapatkan secara nyata dan komplit adalah bagian dari proses berpikir kritis. pengkajian yang selanjutnya yaitu Pengorganisasian atau Pengelompokan data dimana merupakan suatu bagaian dalam proses berpikir kritis untuk meningkatkan kemampuan dalam menginterpretasi status kesehayan klien.

\section{SARAN}

Dalam proses keperawatan terdapat 5 tahapan, tahap awal yaitu pengkaian dimana dalam tahap penhkajian tersebuat juga terdapat tahap yang meliputi pengumpulan data, pemeriksaan data, penilaian data, pengelompokan atau pengorganisasian data dan pendokumentasian hasil pengkajian. Sebagai suatu profesi yang memberikan pelayanan tentunya Perawat harus mampu melaksanakan proses keperawatan dengan benar dan baik berdasarkan tahap yang terencana dan beraturan agar tidak terjadi kesalahan yang dapat menyebabkan kerugian karena mutu pelayanan keperawatan itu sendiri ditentukan oleh perawat yang kompeten dalam bidangnya sehingga kualitas pelayanan kesehatan dapat ditingkatkan lagi. 


\section{DAFTAR PUSTAKA}

Dermawan, Deden. (2012). Proses Keperawatan : Penerapan Konsep Dan Kerangka Kerja. Yogyakarta : Gosyen Publishing.

Deswani. (2009). Proses Keperawatan dan Berpikir Kritis. Jakarta : Salemba Medika.

Haryanto. (2007). Konsep Dasar Keperawatan Dengan Peemetaan Konsep. Jakarta : Salemba Medika.

Hidayat, A. A. (2002). Pengantar Dokumentasi Proses Keperawatan. Jakarta:EGC.

Lismidar,H.(1990).Proses

Keperawatan. Jakarta : Universitas

Indonesi.

Maryan,S, Santun ,S. (2007). Buku Ajar Berpikir Kritis Dalam Proses Keperawatan. Jakarta : EGC.

Nursalam. (2001). Proses dan Dokumentasi Keperawatan Konsep dan Praktik. Jakarta: Salemba Medika.
Potter \& Perry. (2005). Buku Ajar Fundamental Keperawatan Konsep Proses Dan Praktik Edisi 4. Jakarta : EGC.

Potter \& Perry. ( 2010). Fundamental Of Nursing : Edisi 7. Jakarta : EGC.

Rohman, Nikmatur \& Saiful W. (2013). Proses Keperawatan : Teori dan Aplikasi. Yogyakarta: AR-RUZZ MEDIA

Roper, Nancy. (1996). Prinsip-Prinsip Keperawatan. Yogyakarta : Andi Yayasan Essentia Medica.

Setiawan, Santun \& Agus, C. (2007): Panduan Praktis Pengkajian Fisik Keperawatan. Jakarta. TIM.

Simamora, R. H. (2009). Dokumentasi keperawatan. Jamber University Press.

Simamora, R. H. ( 2010). Komunikasi Dalam Keperawatan. Jamber University Press. 
Simamora, R. H. (2008). Peran Manajemen Pembinaan Etika Perawat Pelaksanan Dalam Peningkatan Kualitas Pelayanan Asuhan Keperawatan. Jurnal IKESMA.

Talbot,L.A.\& Mayers,Mary (1997).Pengkajian Keperawatan Kritis:

Edisi 2. Jakarta. EGC

Tarwoto \& Wartonah. (2012). Kebutuhan Dasar Manusia Dan Proses Keperawatan. Jakarta : Salemba Medika. 